\title{
Alpha-1-Antitrypsin expressing Mesenchymal Stem Cells (MSC-AAT) for the treatment of severe cases of COVID-19 infection
}

\author{
Authors \\ Manfred Stangl MD PhD, Department of Surgery, Klinikum Großhadern \\ Ludwig-Maximilians-University, Munich, Germany \\ Felix Hermann, Apceth Biopharma GmbH, Munich, Germany \\ Frank Scheidemann, JunctuCell Biomed Manufacturing GmbH, Hohenbrunn, Germany \\ Michael Strassmair MD, JunctuCell Biomed Manufacturing GmbH, Hohenbrunn, Germany \\ Corresponding Author: Manfred Stangl MD PhD, Klinikum Großhadern, Department of \\ Surgery, Marchioninistr.15, 81377 Munich, Germany, manfred.stangl@med.uni- \\ muenchen.de
}

\begin{abstract}
With the outbreak of the COVID-19 pandemic, the search for specific forms of therapy began. Especially severe courses with multiorgan failure and the resulting long-term damage pose a particular challenge. The better understanding of immunological correlations in the context of the infection allowed the identification of specific infection pathways of the virus into the body cells as well as mechanisms in the development of a fatal cytokine release syndrome (CRS). Early clinical studies with mesenchymal stem cells could show a side-effect free modulating effect on this excessive immune reaction. In the severely affected regions of Northern Italy, coincidence with a latent congenital alpha-1 antitrypsin deficiency was observed. In vitro experiments demonstrated an anti-infective and immunoregulatory effect of alpha-1antitrypsin. Low plasma levels of this acute phase protein appear to play a central role in the development of severe and fatal disease. The combination of both principles in a genetically engineered stem cell with the ability to express alpha-1-antitrypsin seems logical. This cell therapy with its specific effect could be used especially in patients with a severe course of disease and a cytokine release syndrome.
\end{abstract}


Since a corona virus outbreak occurred in Wuhan China at the end of 2019, 23,687,271 patients worldwide have been infected with the SARS-CoV-2 virus. 814,248 patients have died from COVID-19 infection by August 24, 2020. The clinical signs of COVID-19 infection range from mild symptoms such as sore throat or cough to severe clinical manifestations of acute respiratory syndrome (ARDS). In addition, kidney failure, shock and cardiac arrhythmia may occur.

To date, no specific therapy is available.

By search for early indicators of severe disease progression the proinflammatory cytokine IL6 in particular has proven to be prognostically unfavorable. McElvaney et al (1) measured the cytokine profile and the response of the acute phase protein alpha-1 antitrypsin (AAT) in 55 COVID-19 patients and 15 healthy volunteers. The proinflammatory cytokines IL-1 beta, interleukin 6, interleukin 8 and sTNFR1 were elevated in all patients with Covid-19 disease. Regarding these cytokines, patients with a mild infection could be clearly differentiated from patients with a severe clinical course. All patients also showed an immune response with the acute phase protein alpha-1-antitrypsin. However, this immune response was not sufficient to compensate a cytokine storm of IL-6. Especially the ratio of IL-6:AAT was significantly higher in patients requiring intensive medical treatment. The increase of IL6:AAT could predict a prolonged intensive care stay and increased mortality. An improvement of IL6:AAT was associated with better clinical outcome (Figure 1).

In more severe forms of the infection, different organ systems are progressively affected. Which organs suffer most seems to depend on the level of expression of the ACE2 receptor in the tissue. (Figure 2)(2). In the acute phase, the lungs and kidneys are of particular clinical importance. Depending on the individual immune response of the patient, a Cytokine Release Syndrome (CRS) will take place. In these cases the release of TNF-alpha plays a central role. The reaction cascades are primarily triggered and maintained by interferon type I and type III as well as the interleukins IL-1, IL-6 and IL-18. A simultaneous activation of the cellular defense mechanisms leads to a cycle which, caused by the release of proteolytic enzymes, leads organ tissue damage. (2) 


\section{Alpha-1 Antitrypsin}

A deficiency of alpha-1 antitrypsin (AAT) thus appears to be a negative prognostic factor for the development of a severe course of COVID-19 infection. This suggests the possibility of a therapeutic use of AAT. This acute phase protein intervenes at different points in the life cycle of the virus as well as in the course of the disease.

The high death rates as well as the conspicuous accumulation of severe infection courses in northern Italy raised the question of the cause of this regional peculiarity. A systematic investigation showed a striking coincidence with an endemic latent alpha-1 antitrypsin deficiency in patients in this region (Figure 3) (3). This was identified as an opportunity to investigate the role of the acute phase protein alpha-1-antitrypsin in the context of SARS-CoV 2 virus infection.

The primary route of infection is by infecting the host cells via a coupling of the virus spike to the membrane protein TPMRSS2 of the ACE2 receptor. Wettstein et. al. (4) could demonstrate that this mechanism is inhibited by alpha-1 antitrypsin in a dose-dependent manner. This results in a reduction of the spike expression level of the virus. (5) As the infection progresses, tissue proteases increase as part of the immune response. Especially trypsin and elastase enable virus absorption on the cell surface. This means a second, receptor-independent infection pathway. Here, the effectiveness is over 100 times higher (6). At the same time, an increased protease level leads to an activation of the spike protein which facilitates the binding to the receptor of non-infected cells (7). Lysosomal proteases thus play a central role in the maintenance and spread of corona virus infection in the human body (8). The inhibitory effect of alpha-1-antitrypsin on endogenous proteases has long been known and proven (9). In the focus of an infection with a SARS-CoV 2 virus, a therapeutic increase of plasma AAT levels may be useful to reduce the spread of the virus in the body after initial infection.

In more severe forms of the infection, different organ systems are increasingly affected. In the acute phase, the lungs and kidneys are of particular clinical importance. Depending on the strength of the immune response, a cytokine release syndrome (CRS) can develop. The release of TNF-alpha plays a central role here. The reaction cascades are primarily triggered and continued by interferon type I and type III as well as by the interleukins IL-1, IL-6 and IL-18. A simultaneous activation of the cellular defense mechanisms leads to a cycle which, via the release of proteolytic enzymes, leads to organ damage (2). 
Besides its inhibitory properties on proteases, alpha-1-antitrypsin shows a recognizable immunomodulating effect. The expression of TNF-alpha is significantly reduced. It also causes a slowdown of the cellular response by reducing the number of neutrophils, which leads to a decrease of the cytokine level of CK(CXCL1). By lowering the protein-1 mRNA level, the cellular transcription rate for interleukin release is reduced (10). Alpha-1-antitrypsin can therefore act in different ways in SARS-CoV 2 virus infections. It slows down the spread of the virus, inhibits the action of proteolytic enzymes on organ tissue and has a modulating effect on the physiological immune response. An uncontrolled immune response, especially with an excessive release of proteases, is a therapeutic challenge not only in acute situations. Due to the tissue damage caused here, constant impairment of the organ systems remains to be feared even after infection.

\section{Mesenchymal stem cells (MSC)}

In the search for an ideal therapy against a Covid-19 infection and its subsequent damage, mesenchymal stem cells (MSC) have increasingly come into focus. In addition to the known immunomodulating properties of these cells, it is also the first-pass effect after intravenous administration with a homing in the lung, which makes a therapy with MSC attractive. All the potential disadvantages of MSC therapy (pooling of cells in the lung) are reversed if lung diseases are to be the target of treatment (11).

Mesenchymal stem cells have the potential to modulate excessive immune responses and accumulate in inflammatory tissue.

First clinical results with single applications showed an unproblematic application without significant side effects. An increase of lymphocytes as well as T-cells could be achieved within a period of two days. In addition, a significant decrease in serum levels of IL-6, TNF-alpha and CRP was found (Figure 4). Parallel to the normalization of the laboratory parameters an improvement of the clinical symptoms as well as the radiological findings was observed (12). In addition to case descriptions, two clinical studies were published by the end of August 2020, each with 7 and 31 patients, respectively, in which patients with Covid-19 disease MSC were administered. Leng et al (13) included 10 patients in one study ( 7 patients verum group, 3 patients control group). According to the clinical classification of the National Health 
Commission of China (Figure 5), 4 patients had a severe form, 1 patient had a very severe form and 2 patients had a general form of Covid-19 infection. The patients received $1 \times 10^{6} \mathrm{MSC}$ per kilogram body weight intravenously once. All patients showed significant clinical improvement within a maximum of 3 days after MSC administration. In the control group one patient died and another developed ARDS (Figure 6). In no case were side effects of MSC therapy observed. Guo et al (14) administered up to 3 infusions of MSC ( $1 \times 10^{6}$ per $\left.\mathrm{kg} / \mathrm{KG}\right)$ to a total of 31 patients. No side effects were observed, 30 patients experienced seroconversion of SARS-CoV-2, 27 patients were discharged from the clinic at the time of publication, one patient died of Covid19.

All previous publications on MSC therapy in patients with severe Covid-19 infection show a good response to the therapy without severe side effects.

The conclusions here derive from known mechanisms of intervention of mesenchymal stem cells on local immunological processes. These cells first need an activation by cytokines. This restricts their effect only to tissues in which an inflammatory event is already present. After this activation, they primarily intervene by modulating the cellular immune response and the activity of NK-cells (15).

\section{Alpha-1-antitrypsin expressing stem cells (MSC-AAT)}

After analysis of the current data situation, the use of alpha-1-antitrypsin and/or mesenchymal stem cells is recommended for the treatment of symptomatic cases of COVID19 disease.

Combining both principles in a genetically engineered stem cell expressing Alpha-1-Antitrypsin provides an effective therapy for severely ill patients.

In order to achieve high levels of AAT in the affected tissues (lung), MSCs are a suitable vehicle due to their "homing potential". Besides their modulating effect on immunological processes, mesenchymal stem cells show the ability to accumulate in diseased tissue. A modern therapy concept with a genetically modified stem cell expressing alpha- 1 antitrypsin seems conclusive and reasonable. Own investigations have shown that AAT suppresses the release of cytokines from stimulated fibroblasts in a dose-dependent manner (Figure 7). Genetically modified stem 
cells expressing AAT did not show any change of their immunomodulating properties in in vitro experiments compared to native MSC (Figure 8).

The use of such cells should achieve a clinical improvement, especially in severe cases, by intervening at various points in the disease process. It can be assumed that in the future modern forms of therapy will be required in addition to an effective vaccination.

\section{Summary}

An alpha-1-antitrypsin producing mesenchymal stem cell (MSC-AAT) offers the following therapeutic approaches in the context of a Covid-19 infection.

1) MSCs accumulate in the lung after intravenous administration (homing).

2) MSCs have an immunomodulating effect on proinflammatory cytokines (Cytokine Storm).

3) MSCs prevent the progression of lung disease to pulmonary fibrosis (late damage).

4) AAT hinders the penetration of the virus into the host cell (infection prophylaxis).

5) AAT reduces proinflammatory cytokines (Cytokine Storm). 
Figure 1:

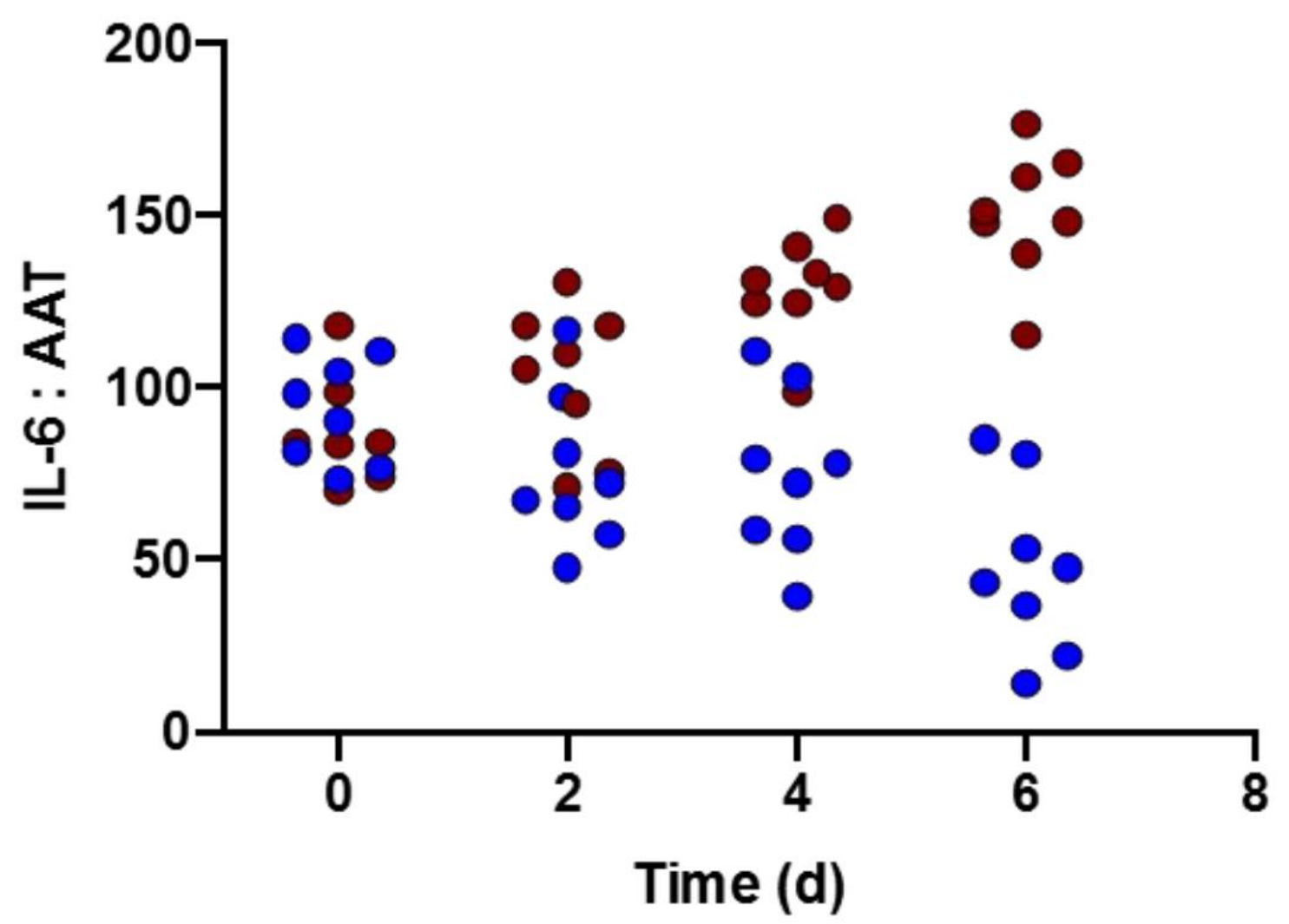

The IL-6:AAT ratio for each patient in the COVIDICU group at each time point is depicted. Patients who went on to good outcome are indicated in blue, while those who went on to poor outcome are indicated in red.

( adapted from McElvaney, O. J., McEvoy, N., McElvaney, O. F., Carroll, T. P., Murphy, M. P., Dunlea, D. M., ... McElvaney, N. G. (2020). Characterization of the Inflammatory Response to Severe COVID 19 Illness. Am J Respir Crit Care Med. doi:10.1164/rccm.202005-15830C) 


\section{Figure 2:}

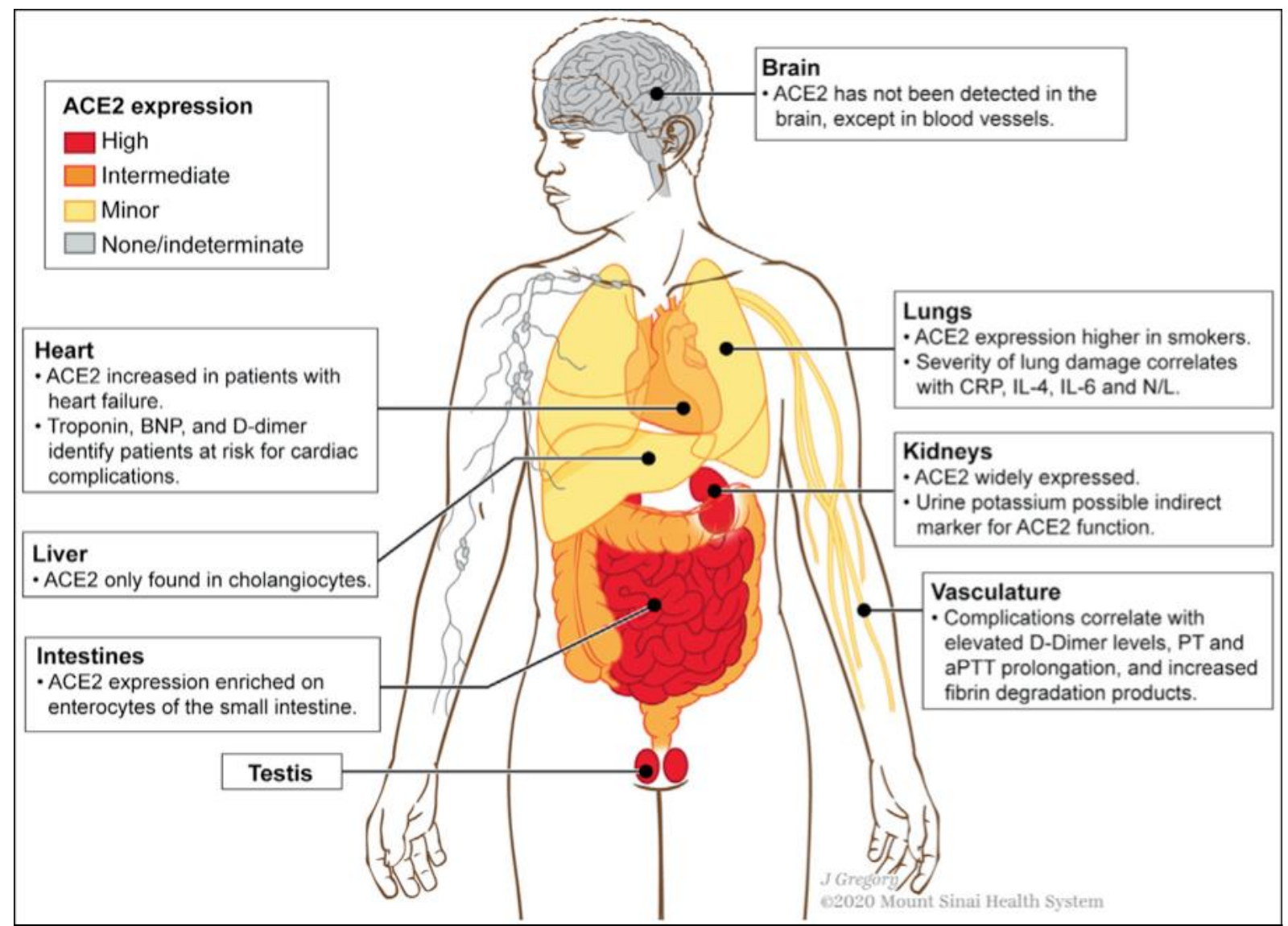

The gastrointestinal tract, kidneys, and testis have the highest ACE2 expressions. In some organs, different cell types have remarkably distinct ex- pressions; e.g., in the lungs, alveolar epithelial cells have higher ACE2 expression levels than bronchial epithelial cells; in the liver, ACE2 is not expressed in hepatocytes, Kupffer cells, or endothelial cells but is detected in cholangiocytes, which can explain liver injury to some extent. Furthermore, ACE2 expression is enriched on enterocytes of the small intestine compared to the colon.ACE2, angiotensinconverting enzyme 2; BNP, B- type natriuretic peptide; CRP, C-reactive protein; IL, interleukin; $\mathrm{N} / \mathrm{L}$, neutrophil-to-lymphocyte ratio; PT, prothrombin time; aPTT, activated partial thromboplastin time.

(adapted from Vabret, N., Britton, G. J., Gruber, C., Hegde, S., Kim, J., Kuksin, M., . . Sinai Immunology Review, P. (2020). Immunology of COVID-19: Current State of the Science. Immunity, 52(6), 910-941. doi:10.1016/j.immuni.2020.05.002) 


\section{Figure 3:}
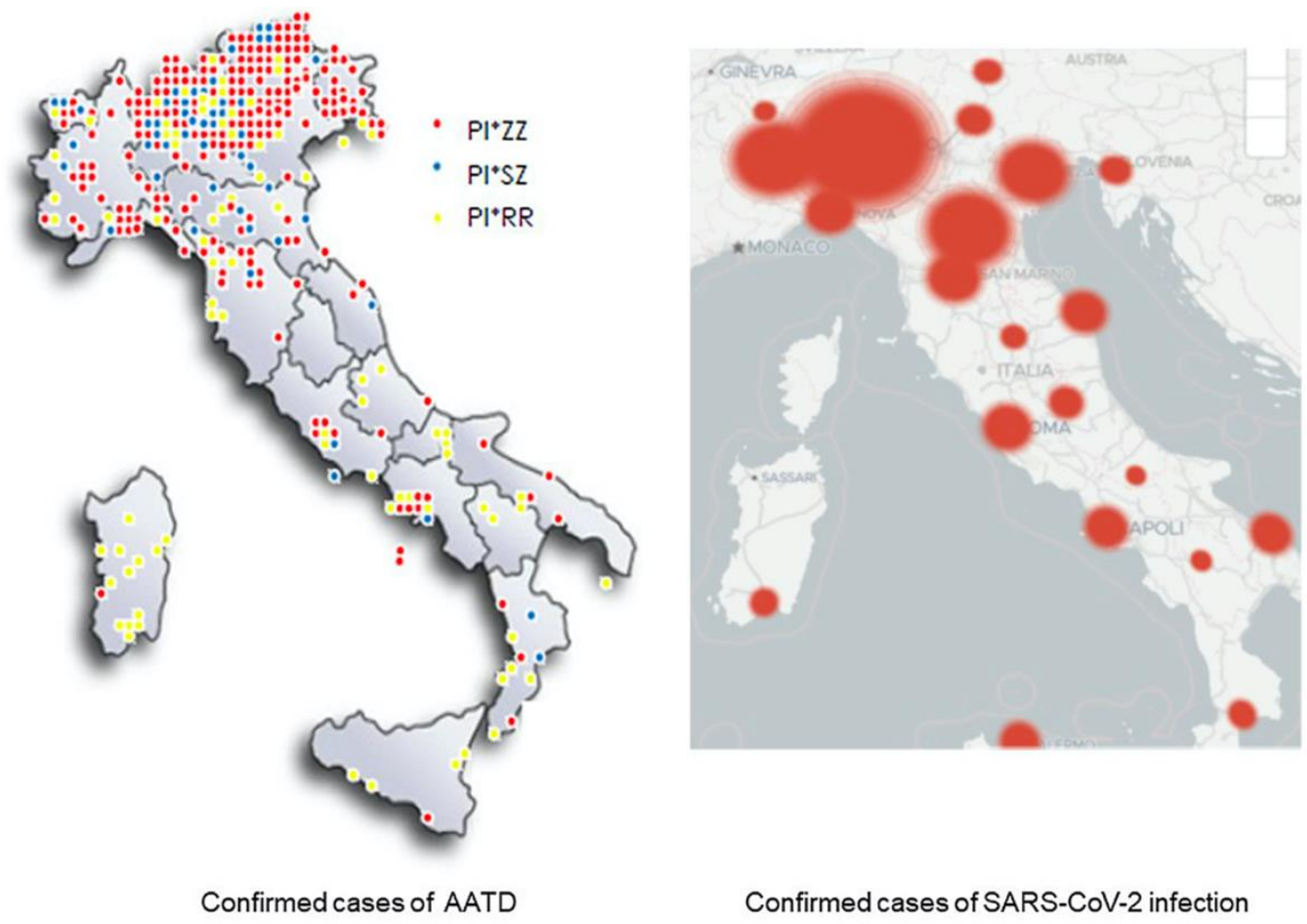

Distribution of confirmed cases of Alpha-1 antitrypsin deficiency and Severe Acute Respiratory Syndrome Coronavirus-2 infection in Italy to 18th April 2020 (AATD = alpha-1 antitrypsin deficiency; SARS-CoV-2 = Severe Acute Respiratory Syndrome Coronavirus-2).

(adapted from Vianello A, B. F. (2020). Geographical Overlap Between Alpha-1 Antitrypsin Deficiency and COVID-19 Infection in Italy: Casual or Causal? Arch Bronconeumol. 2020;S0300-2896(20)30169-1) 


\section{Figure 4:}
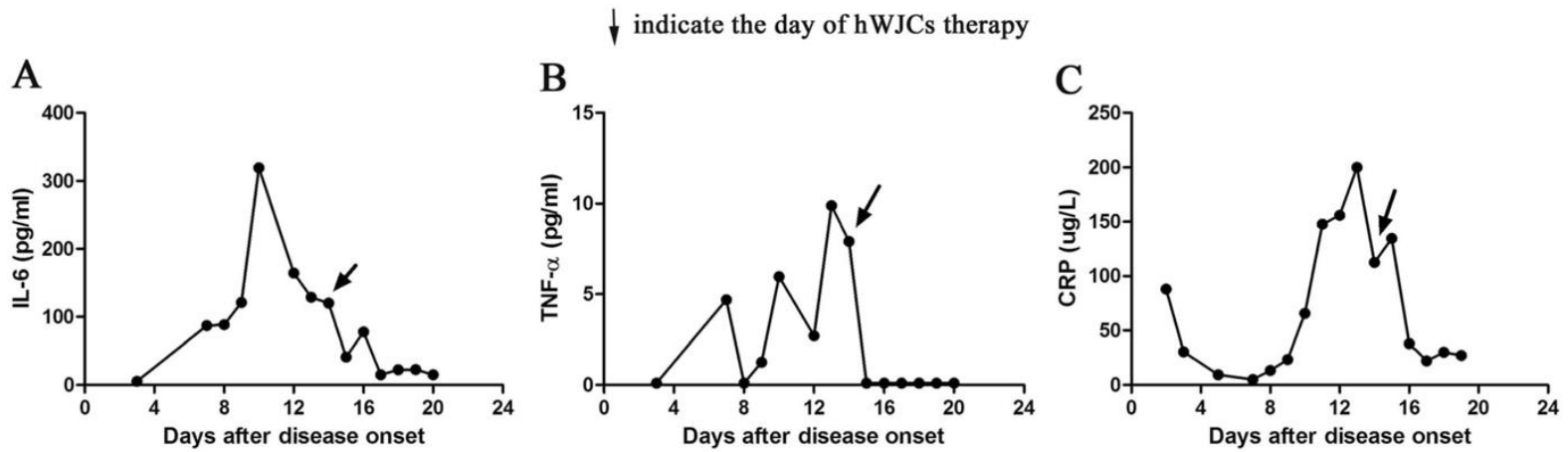

The dynamic changes of IL-6 (a), TNF- $\alpha$ (b), and C-reaction protein (c). The level of plasma Creaction protein, IL-6, and TNF- $\alpha$ was significantly decreased after intravenous injection of hWJCs.

(adapted from : Zhang, Y., Ding, J., Ren, S., Wang, W., Yang, Y., Li, S., Zhou, C. (2020). Intravenous infusion of human umbilical cord Wharton's jelly-derived mesenchymal stem cells as a potential treatment for patients with COVID-19 pneumonia. Stem Cell Res Ther, 11(1), 207.

doi:10.1186/s13287-020-01725-4

\section{Figure 5:}

\begin{tabular}{|c|c|c|c|}
\hline Mild & Common & Severe & Critically severe \\
\hline $\begin{array}{l}\text { Mild clinical } \\
\text { manifestation, } \\
\text { None Imaging } \\
\text { Performance }\end{array}$ & $\begin{array}{l}\text { Fever, } \\
\text { respiratory } \\
\text { symptoms, } \\
\text { pneumonia } \\
\text { performance on } \\
\text { X-ray or CT }\end{array}$ & $\begin{array}{l}\text { Meet any of the followings: } \\
\text { 1. Respiratory distress, } \mathrm{RR} \geq 30 / \mathrm{min} \text {; } \\
\text { 2. Oxygen saturation } \leq 93 \% \text { at rest state; } \\
\text { 3. Arterial partial pressure of oxygen }\left(\mathrm{PaO}_{2}\right) \text { / } \\
\text { Fraction of inspiration } \mathrm{O}_{2}\left(\mathrm{FiO}_{2}\right) \leq 300 \mathrm{mnHg} \text {, } \\
1 \mathrm{mmHg}=0.133 \mathrm{kPa}\end{array}$ & $\begin{array}{l}\text { Meet any of the followings: } \\
\text { 1. Respiratory failure needs mechanical } \\
\text { ventilation; } \\
\text { 2. Shock; } \\
\text { 3. Combined with other organ failure, } \\
\text { patients need ICU monitoring and } \\
\text { treatment }\end{array}$ \\
\hline
\end{tabular}

Clinical classification of the COVID-19 released by the National Health Commission of China. 


\section{Figure 6:}

\begin{tabular}{|c|c|c|c|c|c|c|c|c|c|c|}
\hline & Case 1 & Case 2 & Case 3 & Case 4 & Case 5 & Case 6 & Case 7 & Ctrl 1 & Ctrl 2 & Ctrl 3 \\
\hline Gender & M & $\mathbf{F}$ & $\mathrm{F}$ & $\mathrm{F}$ & $\mathbf{M}$ & $\mathbf{M}$ & $\mathbf{M}$ & $\mathrm{F}$ & $\mathrm{F}$ & F \\
\hline Age (years) & 65 & 63 & 65 & 51 & 57 & 45 & 53 & 75 & 74 & 46 \\
\hline COVID-19 type & $\begin{array}{l}\text { Criticall } \\
\text { y severe }\end{array}$ & Severe & Severe & Common & Common & Severe & Severe & Severe & Severe & $\begin{array}{l}\text { Sever } \\
\text { e }\end{array}$ \\
\hline Fever $\left({ }^{\circ} \mathrm{C}\right.$, baseline $)$ & 38.6 & 37.7 & 38.2 & 38.5 & 38.4 & 39.0 & 39.0 & 36.0 & 38.9 & 37.7 \\
\hline Shortness of breath & $+1+$ & $+H$ & ++ & + & + & +++ & ++ & $+1+$ & + & + \\
\hline $\begin{array}{l}\text { Oxygen saturation } \\
\text { at rest state }\end{array}$ & $89 \%$ & $93 \%$ & $92 \%$ & $95 \%$ & $94 \%$ & $92 \%$ & $90 \%$ & $91 \%$ & $92 \%$ & $93 \%$ \\
\hline $\begin{array}{l}\text { Cough, weak, poor } \\
\text { appetite }\end{array}$ & + & + & ++ & + & ++ & ++ & + & + & $H$ & + \\
\hline Diarrhea & - & - & + & - & - & - & - & - & - & - \\
\hline Date of diagnosed & Jan 23 & $\operatorname{Jan} 27$ & Jan 25 & Feb 3 & Feb 2 & $\operatorname{Jan} 27$ & Feb 3 & Feb 3 & Feb 6 & Feb 5 \\
\hline $\begin{array}{l}\text { Date of intervention } \\
\text { (MSCs or Placebo) }\end{array}$ & Jan 31 & Feb 2 & Feb 4 & Feb 4 & Feb 4 & Feb 6 & Feb 6 & Feb 8 & Feb 6 & Feb 6 \\
\hline Date of recovery & Feb 3 & Feb 4 & $\begin{array}{l}\text { Feb } 6 \\
\text { Discharged }\end{array}$ & $\begin{array}{l}\text { Feb } 6 \\
\text { Discharged }\end{array}$ & $\begin{array}{l}\text { Feb } 5 \\
\text { Discharged }\end{array}$ & Feb 7 & Feb 7 & Dead & ARDS & Stable \\
\hline
\end{tabular}

General informations of the enrolled patients.

(Fig 5 and 6 adapted from Leng, Z., Zhu, R., Hou, W., Feng, Y., Yang, Y., Han, Q., . . Zhao, R. C. (2020). Transplantation of ACE2(-) Mesenchymal Stem Cells Improves the Outcome of Patients with COVID 19 Pneumonia. Aging Dis, 11(2), 216-228. doi:10.14336/AD.2020.0228) 
Figure 7:

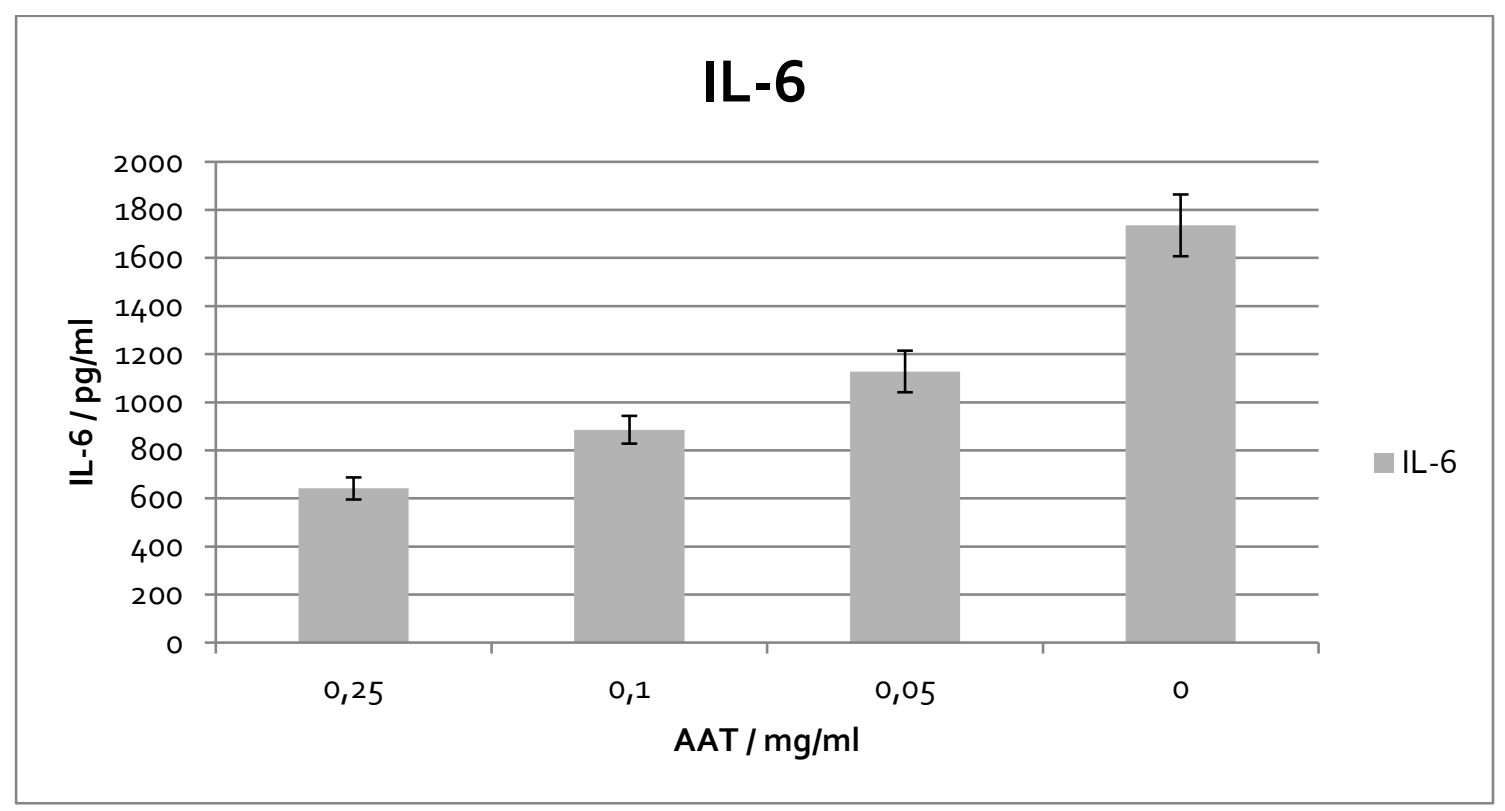

Suppression of II-6 production from stimulated fibroblasts, depending on AAT concentration

Figure 8:

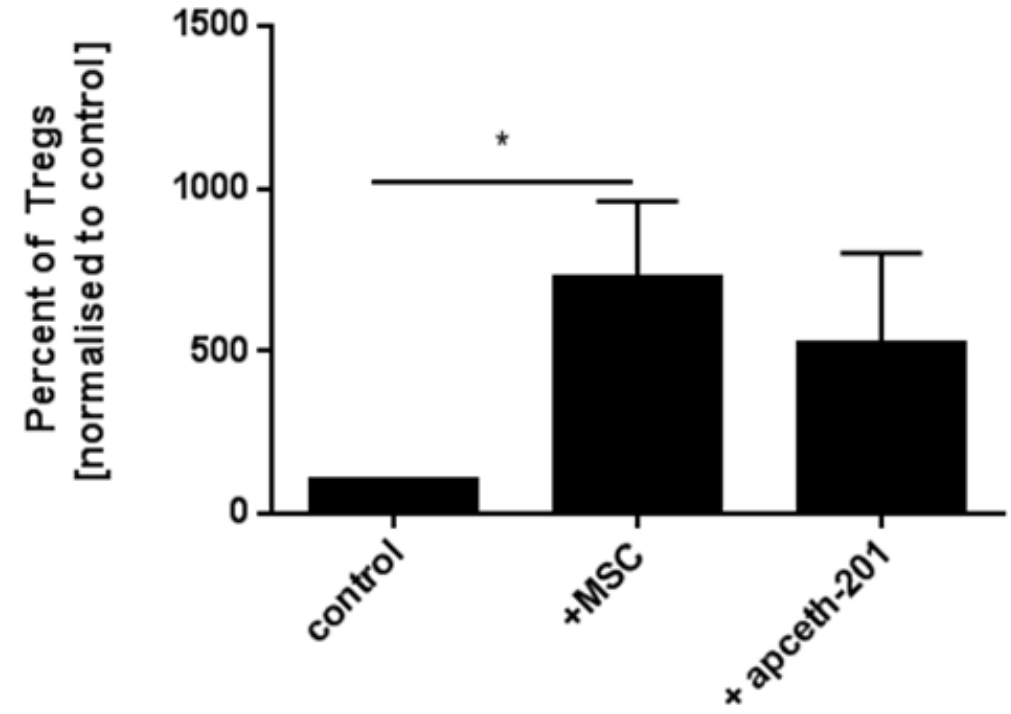

Apceth201 are AAT expressing MSC. No difference in Treg modulation compared with native MSC 


\section{Literature:}

1) McElvaney, O. J., McEvoy, N., McElvaney, O. F., Carroll, T. P., Murphy, M. P., Dunlea, D. M., . .. McElvaney, N. G. (2020). Characterization of the Inflammatory Response to Severe COVID19 Illness. Am J Respir Crit Care Med. doi:10.1164/rccm.202005-15830C

2) Vabret, N., Britton, G. J., Gruber, C., Hegde, S., Kim, J., Kuksin, M., ... Sinai Immunology Review, P. (2020). Immunology of COVID-19: Current State of the Science. Immunity, 52(6), 910-941. doi:10.1016/j.immuni.2020.05.002

3) Vianello A, B. F. (2020). Geographical Overlap Between Alpha-1 Antitrypsin Deficiency and COVID-19 Infection in Italy: Casual or Causal? Arch Bronconeumol. 2020;503002896(20)30169-1.

4) Lukas Wettstein, C. C., Janis A. Müller, Tatjana Weil, Rüdiger Groß, Maximilian Hirschenberger, Alina Seidel, Susanne Klute, Fabian Zech, Caterina Prelli Bozzo, Nico Preising, Giorgio Fois, Robin Lochbaum, Philip Knaff, Volker Mailänder, Ludger Ständker, Dietmar Rudolf Thal, Christian Schumann, Steffen Stenger, Alexander Kleger, Günter Lochnit, Konstantin Sparrer, Frank Kirchhoff, Manfred Frick, Jan Münch, \& https://doi.org/10.1101/2020.07.02.183764, b. d. (2020). Alpha-1 antitrypsin inhibits SARSCoV-2 infection. bioRxiv 2020.07.02.183764; .

5) Nurit P. Azouz, A. M. K., Marc E. Rothenberg, \& (2020). Alpha 1 Antitrypsin is an Inhibitor of the SARS-CoV2-Priming Protease TMPRSS2. bioRxiv 2020.05.04.077826; .

6) Matsuyama, S., Ujike, M., Morikawa, S., Tashiro, M., \& Taguchi, F. (2005). Proteasemediated enhancement of severe acute respiratory syndrome coronavirus infection. Proc Nat Acad Sci U S A, 102(35), 12543-12547. doi:10.1073/pnas.0503203102

7) Millet, J. K., \& Whittaker, G. R. (2015). Host cell proteases: Critical determinants of coronavirus tropism and pathogenesis. Virus Res, 202, 120-134. doi:10.1016/j.virusres.2014.11.021

8) Zheng, Y., Shang, J., Yang, Y., Liu, C., Wan, Y., Geng, Q., . . Li, F. (2018). Lysosomal Proteases Are a Determinant of Coronavirus Tropism. J Virol, 92(24). doi:10.1128/JVI.01504-18

9) James HL, C. A. (1978). Mechanism of inhibition of porcine elastase by human alpha-1antitrypsin. J Clin Invest. 1978;62(6):1344-1353. doi:10.1172/JCI109255

10) Jonigk, D., Al-Omari, M., Maegel, L., Muller, M., Izykowski, N., Hong, J., . . Janciauskiene, S. (2013). Anti-inflammatory and immunomodulatory properties of alpha1-antitrypsin without inhibition of elastase. Proc Natl Acad Sci U S A, 110(37), 15007-15012. doi:10.1073/pnas.1309648110

11) Sinclair, K., Yerkovich, S. T., \& Chambers, D. C. (2013). Mesenchymal stem cells and the lung. Respirology, 18(3), 397-411. doi:10.1111/resp.12050

12) Zhang, Y., Ding, J., Ren, S., Wang, W., Yang, Y., Li, S., Zhou, C. (2020). Intravenous infusion of human umbilical cord Wharton's jelly-derived mesenchymal stem cells as a potential treatment for patients with COVID-19 pneumonia. Stem Cell Res Ther, 11(1), 207. doi:10.1186/s13287-020-01725-4

13) Leng, Z., Zhu, R., Hou, W., Feng, Y., Yang, Y., Han, Q., Zhao, R. C. (2020). Transplantation of ACE2(-) Mesenchymal Stem Cells Improves the Outcome of Patients with COVID-19 Pneumonia. Aging Dis, 11(2), 216-228. doi:10.14336/AD.2020.0228

14) Guo, Z., Chen, Y., Luo, X., He, X., Zhang, Y., \& Wang, J. (2020). Administration of umbilical cord mesenchymal stem cells in patients with severe COVID-19 pneumonia. Crit Care, 24(1), 420. doi:10.1186/s13054-020-03142-8

15) Lee, D. K., \& Song, S. U. (2018). Immunomodulatory mechanisms of mesenchymal stem cells and their therapeutic applications. Cell Immunol, 326, 68-76. doi:10.1016/j.cellimm.2017.08.009 